\title{
Potential drug-food interactions in patients hospitalized in the Cardiology Unit
}

\section{Potenciais interações fármaco-alimento em pacientes internados no Setor de Cardiologia}

\section{A B S T R A C T}

\section{Objective}

To analyze potential Drug-Food Interactions identified in prescriptions of patients admitted to the Cardiology Unit of a university hospital.

\section{Methods}

This is a descriptive, cross-sectional quantitative study carried out in the Cardiology Unit of a university hospital in the city of Rio de Janeiro, Brazil. Data collection took place in archived medical records of hospitalized patients between August and September, 2016.

\section{Results}

In each prescription, there were on average 7.5 drugs mentioned (Standard Deviation of 2.1). Most were tablets (93\%) and antihypertensive drugs (40\%). Two hundred and fifty two potential Drug-Food Interactions were identified. Acetylsalicylic acid and omeprazole were the most potentially interactive drugs.

${ }^{1}$ Universidade Federal do Rio de Janeiro, Centro de Ciências da Saúde, Escola de Enfermagem Anna Nery. R. Afonso Cavalcante, 275, Cidade Nova, Rio de Janeiro, RJ, Brasil. Correspondence to: MK ANJOS. E-mail: <kirtonmatheus@gmail.com>.

2 Instituto Nacional do Câncer, Residência Multiprofissional em Oncologia. Rio de Janeiro, RJ, Brasil.

Article based on the dissertation by MK ANJOS, entitled "Potenciais interações fármaco-alimento em pacientes internados no Setor de Cardiologia". Universidade Federal do Rio de Janeiro; 2016.

\section{How to cite this article}

Anjos MK, Oliveira TCSS, Moreira MB, Moreira SO, Stipp MAC, Paes GO. Potential drug-food interactions in patients hospitalized in the Cardiology Unit. Rev Nutr. 2019;32:e180147. http://dx.doi.org/10.1590/1678-9865201932e180147 


\section{Conclusion}

Drug-Food Interactions occur with commonly used drugs, for example omeprazole and acetylsalicylic acid. However, health teams do not know or identify a substantial part of interactions. This factor leads to an exposure to risks related to changes in drug response and patient safety.

Keywords: Administration, oral. Cardiology service, hospital. Food-drug interactions. Nursing. Patient safety.

\section{RESUMO}

\section{Objetivo}

Analisar as potenciais interações fármaco-alimento identificadas a partir das prescrições medicamentosas de pacientes internados no Serviço de Cardiologia de um Hospital Universitário.

\section{Métodos}

Trata-se de um estudo quantitativo, descritivo e transversal, realizado em uma unidade de internação cardiológica de um Hospital Universitário localizado no município do Rio de Janeiro. A coleta de dados ocorreu em prontuários arquivados de pacientes internados entre agosto e setembro de 2016.

\section{Resultados}

Em cada prescrição haviam em média 7,5 medicamentos, desvio padrão de 2,1, sendo a maioria comprimidos (93\%) e da classe dos anti-hipertensivos (40\%). Identificou-se 252 potenciais interações fármaco-alimento, sendo o ácido acetilsalicílico e omeprazol os medicamentos de maior potencialidade de interação.

\section{Conclusão}

As interações fármaco-alimento ocorrem com medicamentos comumente utilizados, a exemplo do omeprazol e ácido acetilsalicilico. No entanto, parte substancial das interações não são conhecidas ou identificadas pela equipe de saúde, colaborando para exposições aos riscos de alterações na resposta medicamentosa e na segurança do paciente.

Palavras-chave: Administração oral. Serviço hospitalar de cardiologia. Interações alimento-droga. Enfermagem. Segurança do paciente.

\section{NTROD U C TION}

Food nutrients exert important actions in the human organism, for they participate in the structural and functional restoration of organic activities. However, the concomitant ingestion of food with medicinal products may alter their functions, as well as the pharmacokinetics and pharmacodynamics of drug compounds. Such convergence in the living organism is known as DrugFood Interaction (DFI) [1].

Drug-Food Interactions are facilitated because most drugs are prescribed orally, and are generally administered concomitantly with food. This concomitance may directly affect nutrition and drug actions, generating risks such as pharmacological toxicity, severe malnutrition, increase in the costs of treatment, a longer hospital stay, among others [2].

Considering the potentiality of risks, the American Hospital Accreditation Organization, The Joint Commission, has encouraged health professionals to monitor possible DFIs in hospitalized patients since the 1980s [3].

The importance of such monitoring is exemplified especially with elderly patients admitted to the cardiology unit. Diseases such as heart failure may lead to a concomitant use of five or more drugs (polypharmacy), which directly increases the potential for the occurrence of DFls $[4,5]$. 
Controlling and mitigating DFls are important challenges for the health care team in the hospital environment. Nonetheless, nursing protagonism is relevant for being ahead of the supply and evaluation of food acceptability, besides having the challenge of being the professionals who are responsible for drug administration, and must therefore guarantee to the hospitalized patient a continuous and harmless care $[2,3]$.

In this perspective, the occurrence of a DFI immediately results in pharmacovigilance and nutritional vigilance. The multiprofessional team should pay close attention not only to possible drugdrug interactions, but also to DFls [2,3].

Thus, the objective of this study is to analyze potential drug-food interactions identified in prescriptions of patients admitted to the cardiology unit of a university hospital.

\section{METHOD S}

This is a quantitative, cross-sectional, exploratory study on a Cardiology Unit comprising 28 beds of a university hospital in the city of Rio de Janeiro, Brazil.

Working with inpatients was a choice based on the organizational rigor in controlling the dietary and drug administration schedules, which validates the mapping of potential DFIs.

Data collection was performed in October 2016 through the mapping of inpatient prescriptions. For that, a consultation was carried out in medical records of patients hospitalized from August to September 2016.

During this period, 76 patients were hospitalized. In order to determine the number of medical records required to compose a sample, a sample calculation was made using a 5\% error and a 95\% confidence level. A sample of 64 medical records was thus determined. The inclusion criteria were established as: pres. Illegible prescriptions have been deleted.

The choice of 64 medical records was randomly performed, and the first prescription of the first day of the patient's hospitalization was chosen from each record. Through selection, there were no sample losses. All prescriptions were in compliance to the established criteria for the study.

It is highlighted that the choice of the prescription of the first day of hospitalization was due to the fact that hospital staff generally records a larger quantity of prescribed drugs compared to other days [5], which contributes to a better stratification of potential DFIs.

With the support of a standardized form, information regarding the characterization of patients such as gender, age, comorbidities, reasons and length of hospitalization was extracted from the medical record. In the prescriptions, oral drugs were discriminated, with information on description, dosage, and schedule of administration.

To establish interactions between drugs and foods, scientific articles on the subject were used as a basis, as well as the Micromedex Drug Interactions ${ }^{\circledR}$ software. By means of data collection, a descriptive statistical analysis of the results was carried out.

This study is part of an integrated research project entitled Good practices applied to patient safety: a drug administration study. The Research Ethics Committee of the institution, registration No.336.436 - Certificado de Apresentação para Apreciação Ética (CAAE ) No.17589513.0.0000.5238, approved the study. 


\section{RE S U L T S}

The results are presented in three segments: characterization of hospitalized patients, profile of drug prescriptions, and mapping of drug-food DFls.

\section{Characterization of hospitalized patients}

The study consisted of 36 men and 28 women, with individuals between 61 and 80 years-old as the highest recurrence (50.0\%). Of the total number of applicants, 43 individuals had hypertension, 25 had diabetes, and 24 had cardiopathy as underlying diseases. At hospital admission, the most relevant justifications were heart failure (17.1\%) and dyspnea caused by effort (12.5\%), with an average length of stay of 11 to 20 days (48.4\%).

\section{Profile of drug prescriptions}

As for drugs, 483 were prescribed orally. The majority of them(93\%) were tablets. Among other pharmacological presentations, there were capsules, coated tablets, and drops (Table 1).

On average, each prescription contained 7.5 oral drugs (a minimum of three drugs and a maximum of 13 drugs), with a Standard Deviation (SD) of 2.1 and a variance of 4.5. Of these drugs, $40 \%$ were antihypertensives, followed by antiulcers ( $8 \%)$, the former being the class of highest recurrence (Figure 1).

In all 64 prescriptions, 606 administrations were performed on different schedules. From 06:00 to 11:00, 253 (41\%) drugs were administered; from 12:00 to 17:00, 127 (21\%) drugs; and from 18:00 to 23:00, 199 (32\%) drugs. The distribution of schedules can be observed in Table 2 .

\section{Mapping of Drug-Food Interactions}

Of the drug classes with the greatest recurrence in prescriptions (analgesics, antipyretic, antiplatelet, antihypertensive, antiarrhythmic, anticoagulant, antitilipemic, antithrombotic, antiulcer, and coronary vasodilators), there were 252 potential interactions between drugs and food/nutrients.

Table 1. Pharmacological presentation of prescribed drugs. Rio de Janeiro (RJ), Brazil, 2016.

\begin{tabular}{lcc}
\hline Pharmacology & Af & Rf \\
\hline Capsules & 11 & 2.3 \\
Tablets $^{*}$ & 452 & 93.6 \\
Coated tablets & 10 & 2.1 \\
Drops & 6 & 1.2 \\
Solutions & 1 & 0.2 \\
Syrups & 3 & 0.6 \\
\hline Total & 483 & 100.0 \\
\hline
\end{tabular}

Note: *Higher Tablet frequency.

Af: Absolute Frequency; Rf: Relative frequency - \%. 


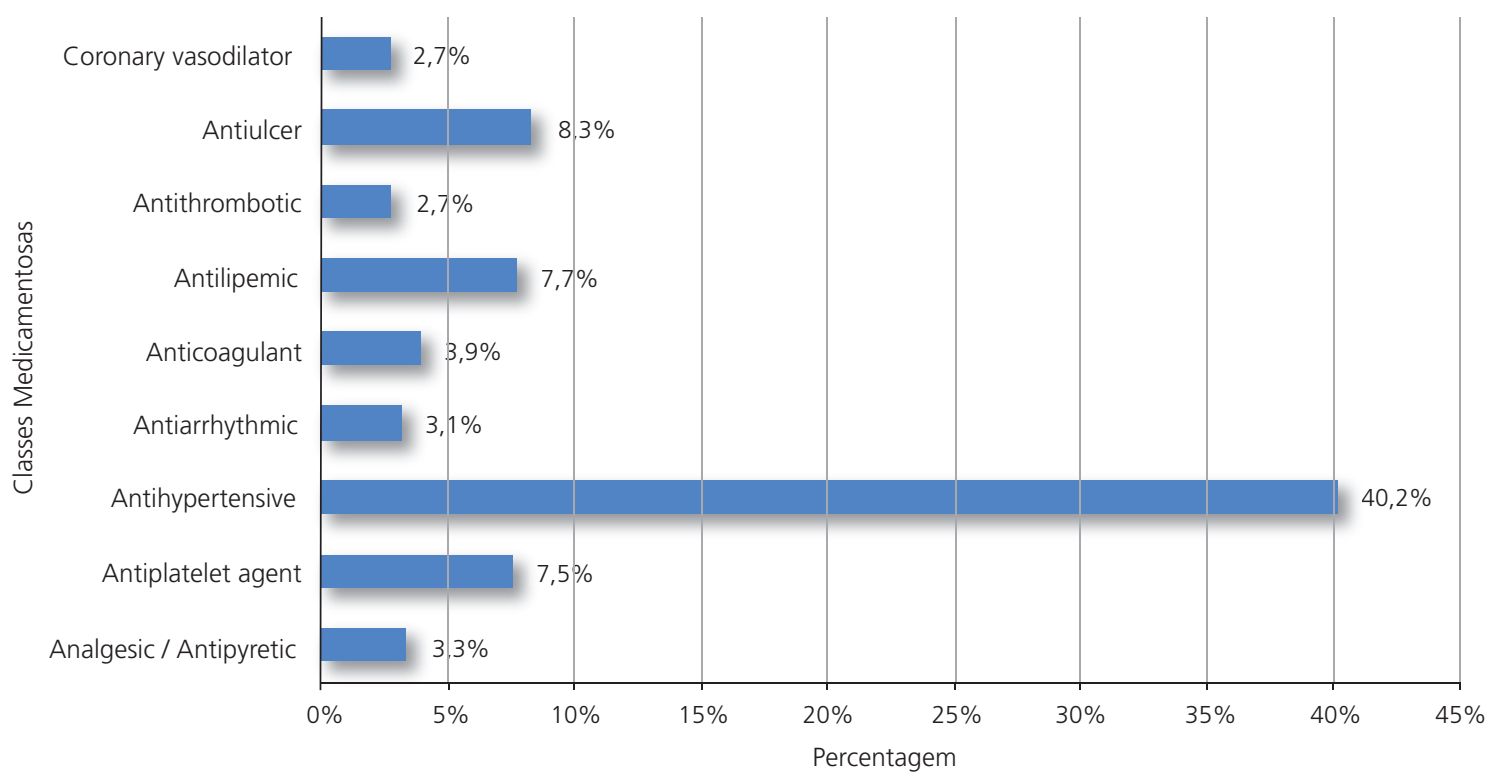

Figure 1. Distribution of drug classes with the greatest rates in prescriptions. Rio de Janeiro (RJ), Brazil, 2016.

Table 2. Administration of drugs and respective schedules according to drug prescriptions. Rio de Janeiro (RJ), Brazil, 2016.

\begin{tabular}{lcc}
\hline Times of administration & Af & Rf \\
\hline $00: 00$ to $05: 00$ & 27 & 4.5 \\
$06: 00$ to $11: 00^{*}$ & 253 & 41.7 \\
$12: 00$ to $17: 00$ & 127 & 21.0 \\
$18: 00$ to $23: 00^{*}$ & 199 & 32.8 \\
\hline Total & 606 & 100.0 \\
\hline
\end{tabular}

Note: *Higher frequency administration of drugs.

Af: Absolute Frequency; Rf: Relative frequency - \%.

The drugs with the greatest potential for drug-food interaction were acetylsalicylic acid (13\%) and omeprazole (13\%). Also noteworthy were atenolol (9\%), carvedilol (8\%), spironolactone (8\%), hydrochlorothiazide (7\%), and warfarin (7\%) (Table 3).

Table 3. Distribution of potential DFI and mechanism/effect of interaction. Rio de Janeiro (RJ), Brazil, 2016.

\begin{tabular}{lcccc}
\hline \multirow{2}{*}{ Drug } & Food/Nutrient & Mechanism/Effect & \multicolumn{2}{c}{ Potential interaction } \\
\cline { 4 - 5 } & & & Af & $\mathrm{Rf}$ \\
\hline Analgesic/Antipyretic & Does not interact with food & 0 & 0.0 \\
Dipyrone & & & \\
Antiplatelet agent & Vitamin C and Vitamin K & Depletes vitamin absorption & 34 & 13.5 \\
Acetylsalicylic Acid (ASA) & Rich in fats & Increases drug absorption & 2 & 0.7 \\
Cilostazol & & & 2 \\
\hline
\end{tabular}


Table 3. Distribution of potential DFI and mechanism/effect of interaction. Rio de Janeiro (RJ), Brazil, 2016.

2 of 2

\begin{tabular}{|c|c|c|c|c|}
\hline \multirow{2}{*}{ Drug } & \multirow{2}{*}{ Food/Nutrient } & \multirow{2}{*}{ Mechanism/Effect } & \multicolumn{2}{|c|}{ Potential interaction } \\
\hline & & & Af & $\mathrm{Rf}$ \\
\hline \multicolumn{5}{|l|}{ Antihypertensive } \\
\hline Anlodipine & Calcium, Potassium and Vitamin D & $\begin{array}{l}\text { Depletes vitamin and mineral } \\
\text { absorption }\end{array}$ & 16 & 6.4 \\
\hline Atenolol & Food in general & $\begin{array}{l}\text { May interfere with the plasma } \\
\text { concentration of the drug }\end{array}$ & 24 & 9.5 \\
\hline Atensine & Does not interact with food & - $^{*}$ & 0 & 0.0 \\
\hline Bisoprolol & Does not interact with food & $L^{*}$ & 0 & 0.0 \\
\hline Carvedilol & Food in general & $\begin{array}{c}\text { Decreases gastrointestinal } \\
\text { discomfort and orthostatic } \\
\text { hypotension }\end{array}$ & 22 & 8.7 \\
\hline Captopril & Food in general & Decreases drug absorption & 12 & 4.8 \\
\hline Clonidine & Does not interact with food & $\perp^{*}$ & 0 & 0.0 \\
\hline Diltiazem & Food in general & Promotes drug absorption & 3 & 1.2 \\
\hline Doxazosin (Carduran) & Does not interact with food & - & 0 & 0.0 \\
\hline Enalapril & Does not interact significantly with food & ـ & 0 & 0.0 \\
\hline Spironolactone & Food in general & $\begin{array}{l}\text { Promotes drug absorption and } \\
\text { retains potassium }\end{array}$ & 21 & 8.3 \\
\hline Furosemide & Food in general & Decreases drug absorption & 16 & 6.4 \\
\hline Hydralazine & Does not interact significantly with food & $\perp^{*}$ & 0 & 0.0 \\
\hline Hydrochlorothiazide & Food in general & Increases drug absorption & 19 & 7.5 \\
\hline Losartan & Does not interact significantly with food & $\perp^{*}$ & 0 & 0.0 \\
\hline Metoprolol & Does not interact significantly with food & $L^{*}$ & $\perp^{*}$ & $-{ }^{*}$ \\
\hline Nifedipine & Food in general (mainly grapefruit) & Increases the drug action time & 1 & 0.4 \\
\hline Valsartana (Brasart) & Does not interact significantly with food & $\perp^{*}$ & 0 & 0.0 \\
\hline \multicolumn{5}{|l|}{ Antiarrhythmic } \\
\hline Amiodarone & Food in general (mainly grapefruit) & Increases drug bioavailability & 9 & 3.6 \\
\hline Digoxin & High-fiber foods & $\begin{array}{l}\text { Decreases absorption and peak } \\
\text { serum concentration }\end{array}$ & 6 & 2.4 \\
\hline \multicolumn{5}{|l|}{ Anticoagulant } \\
\hline Warfarin & Vitamin K-rich foods & Decreases anticoagulation & 18 & 7.1 \\
\hline \multicolumn{5}{|l|}{ Antilipemic } \\
\hline Simvastatin & Grapefruit & Decreases drug bioavailability & & \\
\hline Atorvastatin & Does not interact significantly with food & $\tau^{*}$ & 0 & 0.0 \\
\hline \multicolumn{5}{|l|}{ Antithrombotic } \\
\hline Clopidogrel & Does not interact with food & $\perp^{*}$ & 0 & 0.0 \\
\hline \multicolumn{5}{|l|}{ Antiulcer } \\
\hline Omeprazole & Vitamin $B_{12}$ and iron & $\begin{array}{c}\text { Decreases absorption of Iron } \\
\text { and Vitamin } B_{12}\end{array}$ & 33 & 13.1 \\
\hline Ranitidine & Vitamin $B_{12}$ and iron & $\begin{array}{l}\text { Decreases absorption of Iron } \\
\text { and Vitamin } B_{12}\end{array}$ & 7 & 2.8 \\
\hline \multicolumn{5}{|l|}{ Coronary vasodilator } \\
\hline Isosorbide monitrate & Food in general & Decreases drug absorption & 9 & 3.6 \\
\hline Propatilnitrate (Substrate) & $\begin{array}{l}\text { There are no studies demonstrating } \\
\text { interactions with food }\end{array}$ & $\perp^{*}$ & $\underline{-}^{*}$ & \\
\hline Total of possible interactions & & & 252 & 100.0 \\
\hline
\end{tabular}

Note: _ _No known interaction with food, no mechanism of action or effect in the human organism.

Af: Absolute frequency; Rf: Relative frequency - \%. 


\section{DISCUSSION}

Currently, the Brazilian population undergoes changes in its demographic profile because life expectancy has increased year after year. It is estimated that the average life expectancy of Brazilians will be 80 years until 2025. With such an increase, there is also a change in the epidemiological profile. Chronic-degenerative diseases have become one of the main causes of morbidity and mortality, especially among the male population, which is the most vulnerable population group to such diseases $[6,7]$.

The characterization of the studied population corroborates the current demographic and epidemiological profile of Brazil. Fifty percent of the studied individuals were between 61 and 80 years-old. Most were men (56\%) with chronic diseases such as arterial hypertension, diabetes mellitus, and cardiopathies.

Regarding the reasons for hospital admission, heart failure (17\%) and dyspnea caused by effort $(12 \%)$ were the main causes, which is in line with studies that have evidenced that cardiovascular diseases are the main reasons for admissions in the Sistema Único de Saúde (SUS, Brazilian Unified Health System). Heart failure is the most prevalent cardio-circulatory disease in Brazil [4].

Hospital admission is a measure to recover health. At the same time, the longer the hospitalization time, the greater the risks of complications and injuries to the patient. In addition, the quality of care is related to time, with a mean acceptable period of 6.6 days [8] being stipulated nationally. In the present study, the patients' stay was above average: $48 \%$ had been hospitalized for 11 to 20 days.

Patients in hospital admission receive, during the whole period, adequate drugs and food for the reestablishment of their clinical condition. However, some factors may trigger the ineffectiveness of nutritional and/or pharmacological treatment, such as the occurrence of DFls. The risks of such interactions are greater among the elderly with chronic diseases requiring polypharmacy $[2,9]$.

The most frequently occurring DFls in the hospital environment are related to changes in the absorption rate of drugs, especially in protein-, fat- and fiber-rich diets, by altering the gastric $\mathrm{pH}$ and the gastrointestinal motility, as well as changing important transport proteins [10].

In contrast, some DFls benefit treatment, since some foods can reduce irritation of the gastrointestinal mucosa, favoring drug absorption [11].

Drugs administered orally are absorbed mainly through the gastric mucosa and the small intestine. These are the priority sites for the occurrence of DFls, since food and drugs undergo similar absorption processes in the body $[2,11]$.

This is because most drugs are prescribed orally, especially as solids, due to ease of use, low cost and greater adherence to treatment [12]. This is confirmed by the results of this study: $93 \%$ of the drugs were tablets, followed by capsules (2\%) and coated tablets (2\%).

Another factor that may influence drug and/or dietary absorption is the amount of drugs prescribed. When the prescription exceeds three different drugs, there is a greater possibility for the occurrence of DFls. It may change the drug's effectiveness and generate nutritional deficiency [13]. Regarding the data, each prescription contained on average number of 7.5 drugs, which exponentially increased the chances of a potential drug-food interaction.

The large number of drugs in prescriptions is related to the characteristic of polypharmacy of cardiology patients [14]. Research shows that most patients admitted to the cardiology unit take 
antihypertensives, being this group the one with the greatest recurrence of prescriptions in the present study $[14,15]$.

Drug prescription is organized at different times according to the schedule made by nurses. Most drugs are scheduled for between 06:00 and 22:00, with a higher concentration in the early morning and late evening [16].

Such predominance appears in the results of this study: most drug administrations occurred from 06:00 to 11:00, and from 18:00 to 22:00. The concentration of drugs during these windows increases the occurrence of DFls because, in this period, the main hospital meals are provided, which increases the risk of concurrent eating and drug use [13].

DFls are difficult to identify and recognize, which increases the risk of impairment to the drug and/or food action $[11,12]$. Thus, it is necessary to know and identify potential DFls so that the success of the nutritional and pharmacological therapy can be facilitated.

Two hundred and fifty two potential interactions were identified. The most recurrent drug classes in the studied unit are antihypertensives (40\%), antiulcer (8\%), antilipemic (7\%), and antiplatelet agents (7\%). Of these, the drugs that were most likely to interact were acetylsalicylic acid $(13 \%)$ and omeprazole (13\%). Atenolol (9\%), carvedilol (8\%), spironolactone (8\%), hydrochlorothiazide $(7 \%)$, and warfarin (7\%) also stood out.

Among the drugs with the highest recurrence and interaction probability is Acetylsalicylic Acid (ASA). It is an antiplatelet agent that interacts specifically with vitamin C (found in citrus fruits and some vegetables) by reducing absorption and increasing the excretion of this vitamin. There is also an interaction with vitamin $\mathrm{K}$ (present in vegetables and oils), reducing the organic reserves of this nutrient and causing an increase in the excretion of thiamine, folic acid, and amino acids. It is recommended not to eat foods rich in vitamin $C$ and $\mathrm{K}$ concomitantly or close to the use of ASA, giving preference to using ASA in mealtime intervals $[2,13]$.

Omeprazole, which belongs to the antiulcer class, interacts with vitamin B12 (found at higher amounts in animal proteins) and iron (present in animal, legume, and vegetable proteins), causing depletion and consequently a low absorption of these nutrients. Therefore, in order to avoid such interaction, it is necessary not to use omeprazole together with foods that are sources of vitamin B12 and iron. There should be a period of one or two hours after their ingestion $[2,11,17]$.

Among antihypertensive drugs, four drugs stood out: atenolol, carvedilol, spironolactone, and hydrochlorothiazide. Atenolol interacts with food in general, as it may change the plasma concentration of the drug, decreasing its absorption. It needs to be administered hours after meals $[2,11,18]$.

Spironolactone interacts with food in general, favoring the absorption of the drug, but with retention of potassium. Therefore, it is recommended not to administer the drug together with foods which are rich in this nutrient, such as avocado and banana $[2,11,18]$.

Carvedilol and hydrochlorothiazide, on the other hand, have a beneficial DFI. Their concomitant use is recommended since the contact between food in general and carvedilol reduces gastrointestinal discomfort and orthostatic hypotension caused by the drug, and when in contact with hydrochlorothiazide, it favors its absorption $[2,11,13,18]$.

Finally, warfarin, which belongs to the class of anticoagulants, is the most described and known drug when it comes to DFls. Achieving optimal therapeutic levels of this drug is difficult as it may interact with a wide variety of foods. The best known interaction is with vitamin $\mathrm{K}$ (present in vegetables such as broccoli, cabbage, parsley, and spinach). It reduces the effect of the drug, promoting blood clotting and increasing risks of thrombus $[14,19]$. 


\section{CONCLUSION}

Scientific knowledge about drug-food interactions is extremely important since drug-food interactions occur with commonly used drugs and foods, such as the interaction between omeprazole and vitamin $B_{12}$, found in most animal proteins, and of acetylsalicylic acid with vitamin $C$ and $K$, which are present in citrus fruits and some vegetables and oils, respectively.

It should be noted that some interactions might bring benefits, such as interactions with carvedilol and hydrochlorothiazide. When used concomitantly with food, they reduce gastric discomfort as food favors drug absorption.

Therefore, through the description and identification of potential drug-food interactions in the cardiology unit, this study was able to evidence the need for a better training of the multiprofessional team. Based on a better knowledge on the subject, a safer and harmless care can be provided.

\section{CONTRIBUTORS}

MK ANJOS was responsible for the design and conception of the research project, for the collection, analysis and interpretation of data, and for writing this paper. TCSS OLIVEIRA and MB MOREIRA were responsible for data collection. SO MOREIRA was responsible for reviewing this study. MAC STIPP was responsible for writing and critical review. GO PAES was responsible for research guidance, writing and critical review.

\section{REFERENCES}

1. Lopes EM, Oliveira EAR, Lima LHO, Formiga LMF, Freitas RM. Interações fármaco-alimento/nutriente potenciais em pacientes pediátricos hospitalizados. Rev Ciênc Farm Básica Apl. 2013 [citado 2016 set 28];34(1):131-5. Disponível em: http://repositorio.ufc.br/bitstream/riufc/7944/1/2013_art_lholima1.pdf

2. Lopes EM, Carvalho RBN, Freitas RM. Analysis of possible food/nutrient and drug interactions in hospitalized patients. Einstein. 2010;83(1):298-302. http://dx.doi.org/10.1590/s1679-45082010ao1672

3. Moura MRL, Reyes FG. Drug-nutrient interaction: A review. Rev Nutr. 2002;15(2):223-38. http://dx.doi. org/10.1590/S1415-52732002000200011

4. Wong CY, Chaudhry SI, Desai MM, Krumholz HM. Trends in comorbidity, disability, and polypharmacy in heart failure. Am J Med. 2011;124(2):136-43. http://dx.doi.org/10.1016/j.amjmed.2010.08.017

5. Passos MMB, Santos RC, Bergamini VG, Souza DC. Interações medicamentosas em pacientes internados na clínica médica de um hospital de ensino e fatores associados. Rev Bras Farm. 2012 [citado 2016 out 20]; 93(4):450-6. Disponível em: http://www.rbfarma.org.br/files/rbf-2012-93-4-9.pdf

6. Santos FC, Rosa PV, Rosa LHT, Pribbernow SCM. Avaliação do risco de internação hospitalar de idosos da comunidade no município de Porto Alegre. Estud Interdiscipl Envelhec. 2014 [citado 2016 nov 3];19(3):839-52. Disponível em: http://www.seer.ufrgs.br/index.php/RevEnvelhecer/ article/view/38139/33289

7. Burille A, Gerhardt TE. Chronic diseases, chronic problems: Agreements and disagreements with health services in therapeutic itineraries of rural men. Saúde Soc. 2014;23(2):664-76. http://dx.doi.org/10.1590/S0 104-12902014000200025

8. Rufino GP, Gurgel MG, Pontes TC, Freire E. Evaluation of determining factors of the length of stay in medical clinic. Rev Bras Clin Med. 2012 [cited 2016 Nov 16];10(4):291-7. Available from: http://files.bvs.br/ upload/S/1679-1010/2012/v10n4/a3043.pdf

9. Silveira EA, Dalastra L, Pagotto V. Polypharmacy, chronic diseases and nutritional markers in communitydwelling older. Rev Bras Epidemiol. 2014;17(4):818-29. http://dx. doi.org/10.1590/1809-4503201400040002

10. Bushra R, Aslam N, Khan AY. Food-drug interactions. Oman Med J. 2011 [cited 2016 Dec 4];26(2):77-83. Available from: http://www.ncbi.nlm.nih.gov/pmc/articles/PMC3191675/ 
11. Sandri M, Gewehr DM, Huth A, Moreira AC. Use of medicines and their potential interactions with foods in institutionalized elderly individuals. Sci Med. 2016 [cited 2016 Dec 15];26(4):ID23780. Available from: http:// revistaseletronicas.pucrs.br/fass/ojs/index.php/scientiamedica/article/view/23780/15055

12. Melo DAA, Nascimento ACS, Souza CAS, Silva WB, Faraoni AS. Identification of possible interactions of orally administered drug with food in hospitalized patients. Scientia Plena. 2014 [cited 2016 Jan 10];10(6):064061. Available from: https://www.scientiaplena.org.br/sp/article/view/1859/986

13. Peixoto JS, Salci MA, Radovanovic CAT, Salci TP, Torres MM, Carreira L. Riscos da interação droga-nutriente em idosos de instituição de longa permanência. Rev Gaúcha Enferm. 2012;33(3):156-64. http://dx.doi. org/10.1590/S1983-14472012000300021

14. Mengue SS, Bertoldi AD, Ramos LR, Farias MR, Oliveira MA, Tavares NUL, et al. Acesso e uso de medicamentos para hipertensão arterial no Brasil. Rev Saúde Pública. 2016;50 Supl2:1s-9. http://dx.doi.org/10.1590/s15188787.2016050006154

15. Lombardi NF, Mendes AEM, Luchetta RC, Reis WCT, Fávero MLD, Correr CJ. Análise das discrepâncias encontradas durante a conciliação medicamentosa na admissão de pacientes em unidades de cardiologia: um estudo descritivo. Rev Latino-Am Enferm. 2016;24:e2760. http://dx.doi.org/10.1590/1518-8345.0820.2760

16. Silva LD, Matos GC, Barreto BG, Albuquerque DC. Aprazamento de medicamentos por enfermeiros em prescrições de hospital sentinela. Texto Contexto Enferm. 2013;22(3):722-30. http://dx.doi.org/10.1590/S0 104-07072013000300019

17. Lombardo M, Eserian JK. Fármacos e alimentos: interações e influências na terapêutica. Infarma. 2014 [citado 2017 dez 9]; 26(3):188-92. Disponível em: http://revistas.cff.org.br/?journal=infarma\&page=article\& op=view\&path\%5B\%5D=632\&path\%5B\%5D=pdf_15

18. Campos AFL, Torres SP, Lopes EM, Carvalho RBN, Freitas RM, Nunes LCC. Identification and analysis of antinutritional factors in possible interactions between medications and food/nutrients in hospitalized patients. Einstein. 2011;93(1):319-25. http://dx.doi.org/10.1590/s1679-45082011ao2026

19. Heldt T, Loss SH. Drug-nutrient interactions in the intensive care unit: Literature review and current recommendations. Rev Bras Ter Intens. 2013;25(2):162-7. http://dx.doi.org/10.5935/0103-507X.20130028 


\section{ERRATUM}

In article "Potential drug-food interactions in patients hospitalized in the Cardiology Unit" with DOI: 10.1590/1678-9865201932e180147, published in Revista de Nutrição, 2019;32:e180147, on page 1:

\section{Where is read}

Marluci de Andrade Conceição STIPP

\section{Should read}

Marluci Andrade Conceição STIPP 